\title{
Surface Chlorophyll-a Concentration Spatio-Temporal Variations in the Northern South China Sea Detected Using MODIS Data
}

\author{
Meihong Fang ${ }^{1}$, Weimin $\mathrm{Ju}^{1, *}$, Xiangnan $\mathrm{Liu}^{2}$, Zhifeng $\mathrm{Yu}^{3,4}$, and Feng Qiu ${ }^{1}$ \\ ${ }^{1}$ International Institute for Earth System Science, Nanjing University, Nanjing, China \\ ${ }^{2}$ School of Information Engineering, China University of Geosciences, Beijing, China \\ ${ }^{3}$ Institute of Remote Sensing and Earth Sciences, Hangzhou Normal University, Hangzhou, China \\ ${ }^{4}$ Key Laboratory of Zhejiang Urban Wetland and Regional Change Research, Hangzhou, China
}

Received 27 December 2013, revised 15 September 2014, accepted 14 November 2014

\begin{abstract}
This study examines the spatio-temporal variations in the sea-surface chlorophyll-a (Chl-a) concentration and their associated underlying driving forces in the northern South China Sea (SCS) from 2004 - 2010. A stratified analysis method and the Moderate Resolution Imaging Spectroradiometer (MODIS) Chl-a product, the National Centers for Environmental Prediction (NCEP) reanalysis data, with maps of monsoon winds and current systems were used in this work. Validation indicated that the MODIS-derived Chl-a is in good agreement with in-situ measurements $\left(\mathrm{R}^{2}=0.815\right)$, accurate enough for analyzing the temporal-spatial variations of Chl-a in the northern SCS. The results show that the spatial heterogeneity of the Chl-a concentration was lowest in winter and increased in spring. The seasonal Chl-a concentration dynamics varied spatially and depended predominantly on the distance from the coastline. The most important factors that affect the Chl-a concentration spatial variability were identified as the monsoon, surface current and sea surface temperature (SST).
\end{abstract}

Key words: Chlorophyll-a concentration, Spatio-temporal variations, MODIS data, Stratified analysis, Northern South China Sea

Citation: Fang, M., W. Ju, X. Liu, Z. Yu, and F. Qiu, 2015: Surface chlorophyll-a concentration spatio-temporal variations in the northern South China Sea detected using MODIS data. Terr. Atmos. Ocean. Sci., 26, 319-329, doi: 10.3319/TAO .2014.11.14.01(Oc)

\section{INTRODUCTION}

The South China Sea (SCS) is a marginal sea surrounded largely by lands. The northern part of the SCS has been intensively studied, due mostly to its complex climatic and geophysical conditions characterized by intensive sea-land interactions, the inflow of numerous great rivers (e.g., the Pearl River), the interactions between its surface current and the East Asian monsoon and the intrusion of the subsurface Kuroshio and deep waters from the western Pacific through the Luzon Strait (Webster 1994; Fang et al. 1998; Qu et al. 2006; Liu et al. 2008, 2010). Recent decades have witnessed massive economic growth and urban development over this area, which have accelerated marine environmental deterioration. However, the marine biota, ecology and the human impacts on this area are poorly understood (Morton and Blackmore 2001). A detailed study is thus required to understand the environmental changes and find appropriate ways

\footnotetext{
* Corresponding author

E-mail:juweimin@nju.edu.cn
}

for sustainable development. As one of the important parameters of marine ecology, the chlorophyll-a (Chl-a) concentration has been used as an indicator of phytoplankton abundance, a marker for bioturbation and carbon flux, and a crucial variable for estimating the carbon budget (Boon and Duineveld 1998). This parameter is also important for understanding the ecological system and global environmental change (Venrick et al. 1987; Liu et al. 2002; Chen et al. 2004; Peñaflor et al. 2007). The necessity for studying the spatio-temporal variations in Chl-a concentration across the SCS is further intensified because of the seriously deteriorated marine environment.

Characterized by its high repetitiveness and wide coverage, remote sensing is an effective method for monitoring the marine environment. Satellite observed ocean color imagery has been widely used to retrieve the Chl-a concentration (Tang et al. 1998; Chen et al. 2004; Peñaflor et al. 2007; Siegel et al. 2013; Tilstone et al. 2013). A variety of remote sensing data, including Coastal Zone Color Scanner (CZCS), Sea-viewing Wide Field of View Sensor 
(SeaWiFS), and Advanced Very High Resolution Radiometer (AVHRR), have been utilized to investigate the SCS marine biological processes and environment (Tang et al. 1998, 1999; Liu et al. 2002; Tseng et al. 2005; Siegel et al. 2013). Most of these studies were conducted by combining in-situ measurements and SeaWiFS data. However, SeaWiFS has already exceeded its service life of 7 years and whether it will still function in the future remains uncertain. In recent years the Chl-a product routinely generated using the Moderate Resolution Imaging Spectroradiometer (MODIS) allows for quantitatively analyzing the spatiotemporal variations in Chl-a concentration. The long-term spatio-temporal variations in Chl-a concentration across the northern SCS still remain unidentified to our knowledge.

This study analyzed the spatial and temporal variations in sea-surface Chl-a concentration and the underlying driving forces in the northern SCS based on the long-term MODIS Chl-a product. We intend (1) to validate the MODIS Chl-a product using in-situ measurements, (2) analyze the spatiotemporal variations in sea-surface $\mathrm{Chl}$-a concentration from 2004 - 2010, and (3) explore the sea surface temperature (SST) and current system effects on the spatial and temporal variations in the sea-surface Chl-a concentration.

\section{MATERIALS AND METHODS}

\subsection{Study Area and Cruises}

The northern SCS is located between $109-121^{\circ} \mathrm{E}$ and $18-24^{\circ} \mathrm{N}$ (Fig. 1). It connects the East China Sea and Philippine Sea through the Taiwan Strait and the Luzon Strait, respectively (Fig. 1a). The SCS is a marginal sea that is largely surrounded by land and confined within the Tropic of Cancer. It experiences a monsoonal climate influenced by the Southwest Monsoon in summer and the Northeast Monsoon in winter (Morton and Blackmore 2001). The study area was divided into 12 buffer zones according to the distance away from the shoreline (Fig. $1 \mathrm{~b}$ and Table 1) for better spatial and temporal analysis of the variations in Chl-a and possible underlying driving forces.

Three cruises were conducted to observe Chl-a concentration using R/V Shiyan 3 in the northern SCS to validate the MODIS Chl-a product. The data used for validation were measured during the periods from 16 September to 4 October 2004 (Cruise 1), from 8 to 27 September 2005 (Cruise 2), and from 7 to 29 September 2006 (Cruise 3), respectively (Figs. 1c, d, and e).

The measured Chl-a concentration exhibited distinguishable spatial and temporal variations. Averages of measured Chl-a concentration within individual zones are presented in Fig. 2, decreasing significantly from zones $02-06$. The spatial variability in measured Chl-a was marginal from zones 07 - 12. The measured Chl-a concentration averages over the entire study area were $0.104,0.153,0.130 \mathrm{mg} \mathrm{m}^{-3}$ in 2004, 2005, and 2006, respectively.

\subsection{MODIS Chl-a Concentration Product}

The 1-km MODIS Chl-a concentration product (http:// oceandata.sci.gsfc.nasa.gov) from 2004 - 2010 was used in this study. In total, 403 scenes of the Chl-a concentration images with good coverage for the study area were downloaded and processed using the ERDAS IMAGINE (ERDAS) platform. The monthly average and coefficient variance $(\mathrm{CV})$ of Chl-a were calculated as:

$\operatorname{chl}_{y, m}=\frac{1}{n} \sum_{j=1}^{n} \operatorname{chl} l_{y, m, j}$

where $c h l_{y, m}$ is the average Chl-a concentration in month $m$ of year $y ; c h l_{y, m, j}$ is the $j^{\text {th }}$ value of Chl-a concentration in month $m$ of year $y$.

The 7-year average of Chl-a concentration in month $m$ was calculated as:

$\operatorname{chl} l_{m}=\frac{1}{7} \sum_{y=1}^{7} \operatorname{chl} l_{y, m}$

The inter-annual variability of Chl-a concentration in month $m$ was quantified using the coefficient of variance $\left(C V_{m}\right)$ :

$C V_{m}=\left[\frac{1}{7} \sum_{y=1}^{7}\left(c h l_{y, m}-c h l_{m}\right)^{2}\right]^{1 / 2} \operatorname{chl}_{m}^{-1}$

\subsection{SST Data}

The reanalysis monthly SST fields from the National Centers for Environmental Prediction (NCEP) were used to investigate the relationship between SST and the spatiotemporal characteristics of the sea-surface Chl-a concentration. NCEP reanalysis data was downloaded from the NOAA/OAR/ESRL PSD, Boulder, Colorado, USA, from their web site at http://www.esrl.noaa.gov/psd/ (Kalnay et al. 1996).

The correlation between SST and the Chl-a concentration was assessed for individual zones and months, i.e.,

$$
\begin{aligned}
& R_{z}=\frac{\sum\left[\left(t_{y, m, z}-\overline{t_{z}}\right) *\left(c h l_{y, m, z}-\overline{c h l_{z}}\right)\right]}{\sqrt{\sum\left(t_{y, m, z}-\overline{t_{z}}\right)^{2}} * \sqrt{\sum\left(c h l_{y, m, z}-\overline{c h l_{z}}\right)^{2}}} \\
& R_{m}=\frac{\sum\left[\left(t_{y, m, z}-\overline{t_{m}}\right) *\left(c h l_{y, m, z}-\overline{c h l_{m}}\right)\right]}{\sqrt{\sum\left(t_{y, m, z}-\overline{t_{m}}\right)^{2}} * \sqrt{\sum\left(c h l_{y, m, z}-\overline{c h l_{m}}\right)^{2}}}
\end{aligned}
$$

where $R_{z}$ and $R_{m}$ denote the correlation coefficients between SST and Chl-a concentration for zone $z$ and month $m$, respectively; $t_{y, m, z}$ and $c h l_{y, m, z}$ are the monthly mean SST and monthly mean Chl-a concentration in month $m$ of year $y$ for zone $z$, respectively. $\bar{t}_{z}$ and $\overline{c h l}$ are the monthly mean 
SST and monthly mean Chl-a concentration averages over all months in the study period for zone $z$, respectively; $\overline{t_{m}}$ and $\overline{c h l_{m}}$ are the monthly mean SST and monthly mean Chla concentration averages over all zones for month $m$ of all years, respectively.

\subsection{Assessment of MODIS Chl-a Concentration Accuracy}

The monthly mean MODIS Chl-a concentration calculated using Eq. (1) was compared with the quasi-synchronous (a)

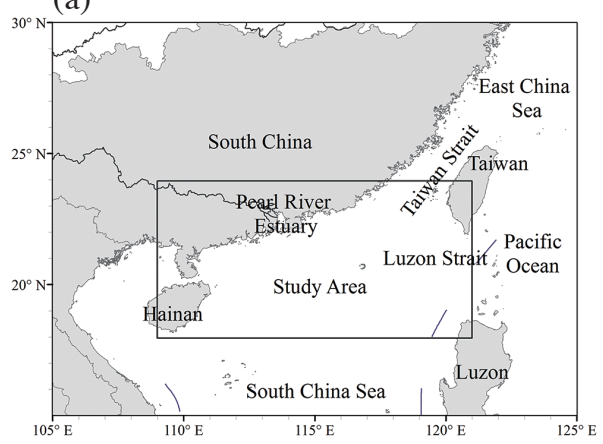

(c)

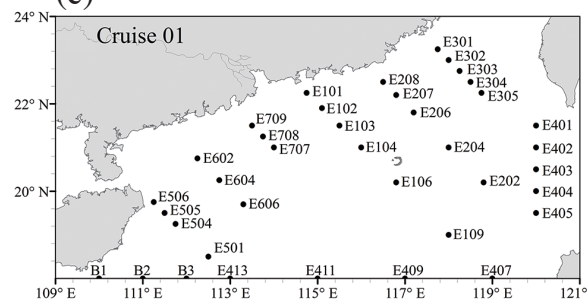

(e)

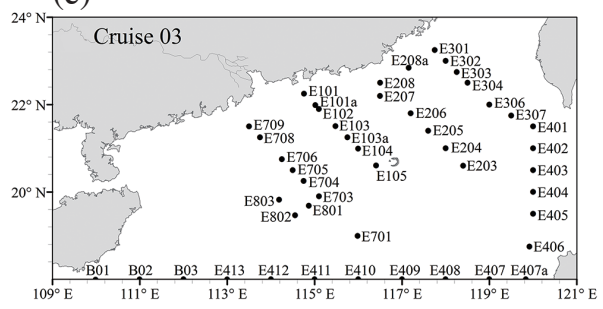

(b)

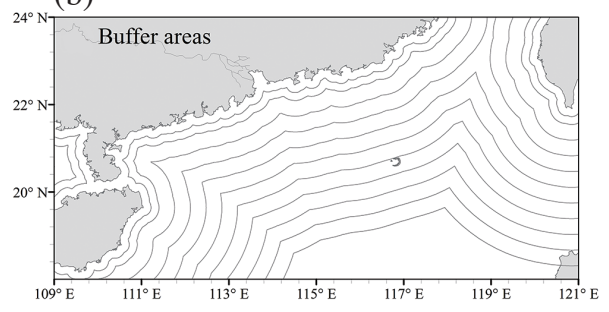

(d)

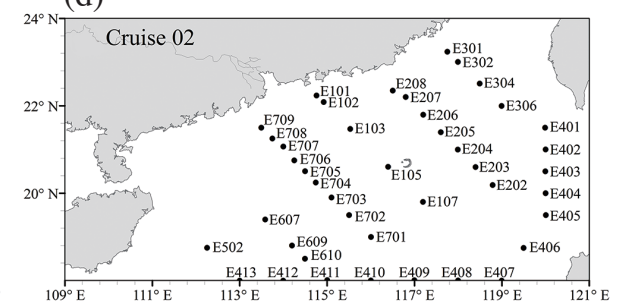

Fig. 1. (a) Study area, (b) buffer areas, and (c) - (e) in-situ stations of 3 cruises in September (2004 - 2006).

Table 1. Buffer areas in northern SCS divided by the distance off the coastline.

\begin{tabular}{cc}
\hline Zonal & Distance $(\mathbf{k m})$ \\
\hline zone01 & $0-20$ \\
zone02 & $20-40$ \\
zone03 & $40-80$ \\
zone04 & $80-120$ \\
zone05 & $120-160$ \\
zone06 & $160-200$ \\
zone07 & $200-240$ \\
zone08 & $240-280$ \\
zone09 & $280-320$ \\
zone10 & $320-360$ \\
zone11 & $360-400$ \\
zone12 & $>400$ \\
\hline
\end{tabular}

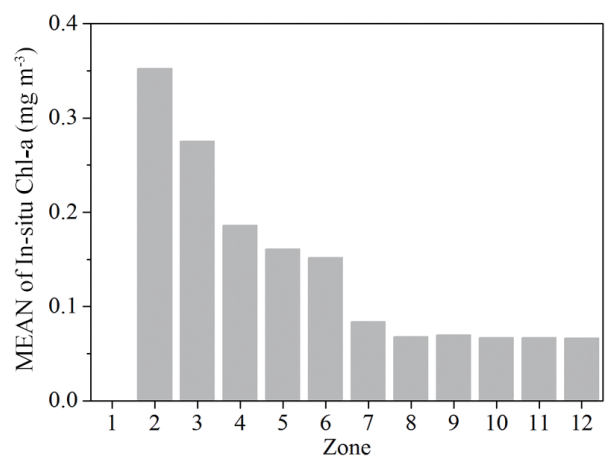

Fig. 2. Mean values of in-situ measured Chl-a concentrations in different zones $(2-12)$ averaged over three cruises. 
cruise observations to assess the MODIS Chl-a concentration product quality in the northern SCS.

The study area was frequently covered by clouds. The monthly averaged image application increased the good data coverage. A cruise took about 1 month in September. So, the comparison of monthly average of remotely sensed Chl-a concentration with the measurements taken in a cruise is acceptable. The linear regression analysis between the insitu measurements and MODIS-derived Chl-a concentration was performed.

\section{RESULTS AND DISCUSSION}

\subsection{Validation of MODIS Chl-a Concentration}

Remotely sensed parameters validation is important for bettering their applications. For Type I waters the uncertainties in Chl-a concentration retrieved from remote sensing were normally less than $\pm 35 \%$ over the range of $0.05-50 \mathrm{mg} \mathrm{m}^{-3}$ (Tang et al. 2003). Figure 3 shows that the consistency between the MODIS derived Chl-a and insitu measurements was generally high, with the exception of samples taken at locations near the river mouths and within the shallow waters (Figs. 1 and 2), where MODIS-derived Chl-a values were higher than in-situ measurements, such as at stations E101, E208, E401, and E505 (Figs. 1b, c, and d). This can be attributed to high suspended sediment from river discharges. In contrast, at Station E506 nearby Hainan Island the MODIS Chl-a concentration was lower than the in-situ measurements. Overall, MODIS Chl-a concentration was in good agreement with the measurements, with a determination coefficient $\left(\mathrm{R}^{2}\right)$ of 0.604 . When sample E506 was excluded the $\mathrm{R}^{2}$ will increase to 0.815 . The $\mathrm{R}^{2}$ values are 0.858 and 0.726 , significant at levels of 0.001 and 0.05 (2-tailed), for Type I and II waters, respectively.

Although the in-situ and satellite measurements are not strictly synchronous, the comparison showed a general consistency between them (Fig. 3). But MODIS data overestimated Chl-a in the two types of water waters and the overestimation increased lineally with the increase in Chl-a concentration. We also compared the result with previous works, the MODIS Chl-a product has been evaluated in the eastern Arabian Sea by Tilstone et al. (2013), in the Antarctic, Equatorial Pacific, California Current, western midPacific, and the West Florida Shelf by Carder et al. (2004), in the Argentine continental shelf and shelf-break regions by Dogliotti et al. (2014), in the Celtic Sea, the Western English Channel and North Sea by Blondeau-Patissier et al. (2004). These works reported that although there were no significant differences between the in-situ measured and MODIS Chl-a concentration, MODIS underestimated Chl-a in the Argentine continental shelf and at shelf-break regions, and overestimated it in the North Sea. This inconsistency is due to the optically active substance in the water column. MODIS data provided biased estimation in water regions where the Inherent Optical Properties (IOP) are determined by phytoplankton and also by absorption due to colored dissolved organic material (CDOM) and scattering by Total Suspended Matter (TSM) (Prieur and Sathyendranath 1981; Sathyendranath et al. 2001; Blondeau-Patissier et al. 2004; Carder et al. 2004; Tilstone et al. 2013; Dogliotti et al. 2014). Based on these works the MODIS Chl-a product is capable of analyzing the spatio-temporal variations in the Chl-a concentration in the northern SCS. To effectively minimize the overestimation we used the relationship between the MODIS and measured Chl-a to correct MODIS Chl-a data through stretching and resampling values.

\subsection{Seasonal Variations of Chl-a Concentration}

Figure 4 shows the spatial distribution of 7-year mean Chl-a concentration in different months, which presents distinguishable seasonality in the northern SCS.

In April prior to the onset of the summer southwest monsoon, the sea-surface Chl-a concentration was low in the entire region (Fig. 4d). It was mostly below $0.3 \mathrm{mg} \mathrm{m}^{-3}$ in the central area, relatively lower than that in other areas. The lowest Chl-a concentration occurred at the inner portion, labeled as A in Fig. 4d, in which the concentration was even below $0.1 \mathrm{mg} \mathrm{m}^{-3}$. In contrast, the relatively high Chl-a concentration $\left(>1.0 \mathrm{mg} \mathrm{m}^{-3}\right)$ was limited to a narrow zone along the coast. The high Chl-a concentration along the coast was related to the high dissolved inorganic nitrogen (DIN) concentration there (Huang et al. 2003; Cai et al. 2004; Liu et al. 2012).

In summer (Figs. 4f, g, and h) the sea-surface Chl-a concentration increased slightly in comparison with the values in April. The summer southwest monsoon drives Chl-a to distribute evenly in the central part. High Chl-a concentration can be observed in the coastal waters. During the inter-monsoon period in September the Chl-a concentration again decreased to low values (Fig. 4i), similar to those during the spring inter-monsoon period (Fig. 4d).

The Chl-a concentration was higher in winter (Figs. 4a, b, k, and l) than in other seasons in the entire area. It also exhibited a distinct spatial pattern, higher in the northeast and lower in the southwest. Obviously, in December (Fig. 4l) and January (Fig. 4a), the patches with high Chl-a concentration existed in areas off northwest Luzon. A similar spatial pattern in the Chl-a concentration in winter was also reported by Liu et al. (2002). Such Chl-a concentration spatial patterns were likely caused by upwelling and the interactions between the northward flowing Luzon coastal current and the westward intrusion of Kuroshio. The positive wind stress curl was possibly another driver for this phenomenon (Peñaflor et al. 2007).

From November to February (Figs. 4a, b, k, and l), a band of high Chl-a concentration (up to $3 \mathrm{mg} \mathrm{m}^{-3}$ ) in the coastal zone was observed. It was about $100 \mathrm{~km}$ in width, extending 
(a)

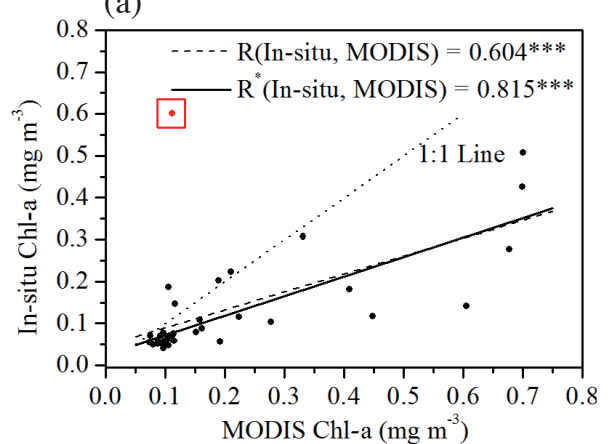

(b)

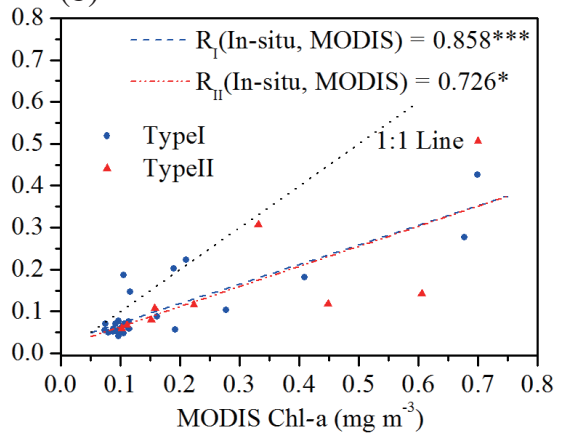

Fig. 3. Comparison of in-situ measured and MODIS Chl-a concentrations for both Type I and II waters (a) and separately for Type I and II waters (b). Symbols * and *** indicate significance level of 0.05 (2-tailed) and 0.001 level (2-tailed), respectively. The red box in (a) denotes data from Station E506.

(a)

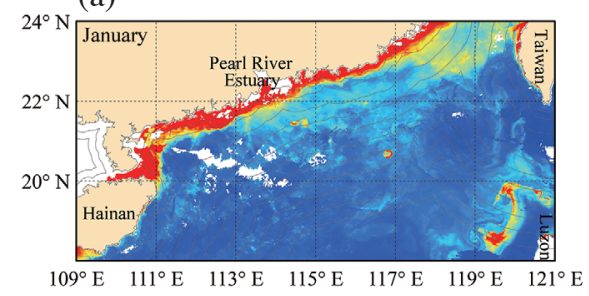

(d)

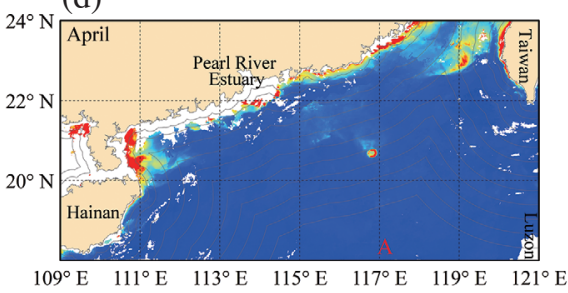

(g)

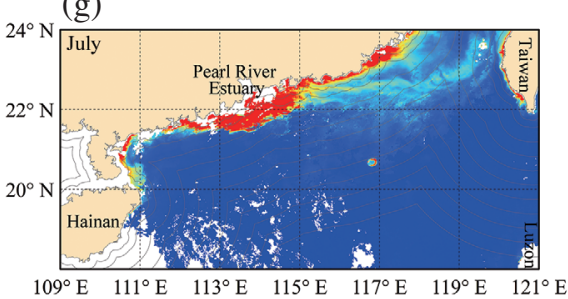

(j)

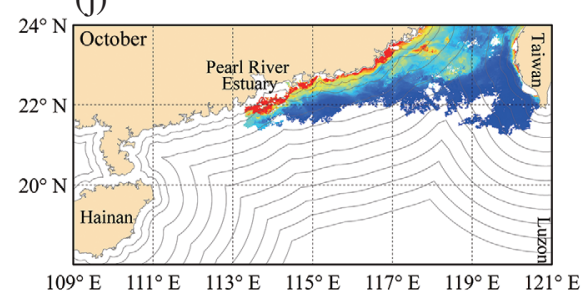

(b)
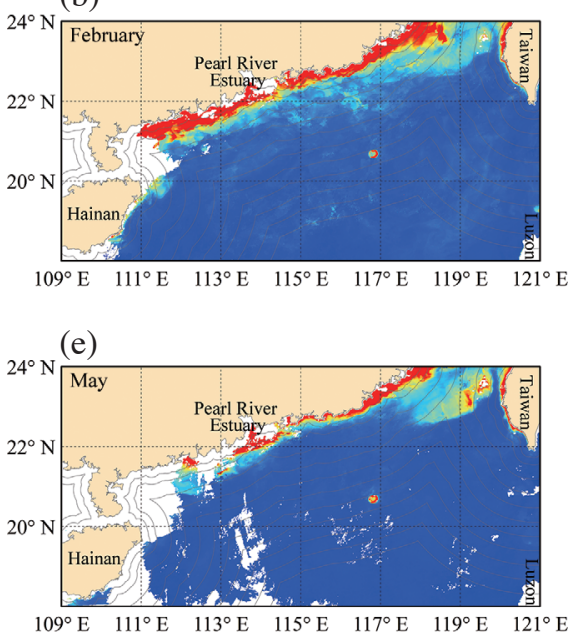

(h)

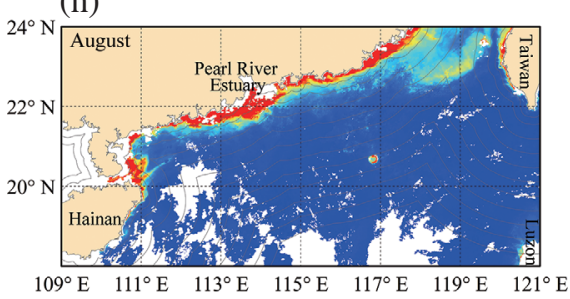

(k)

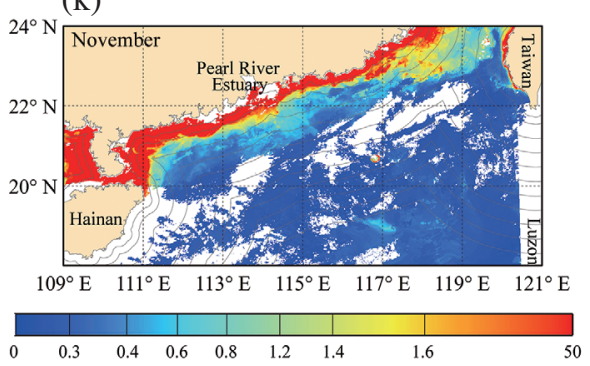

(c)

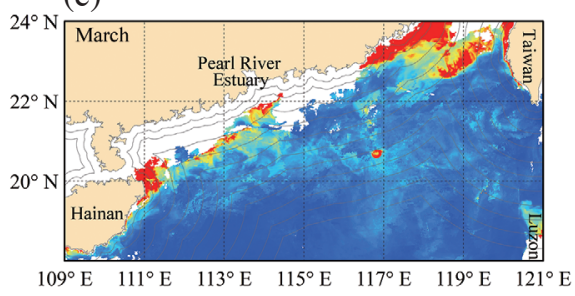

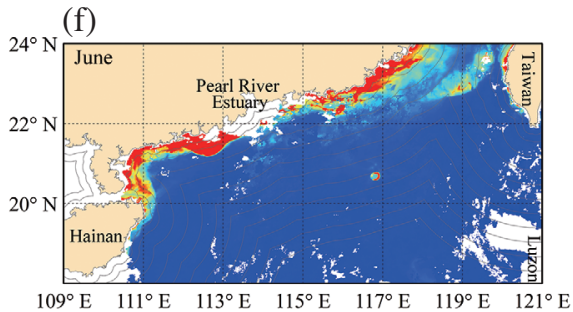

(i)

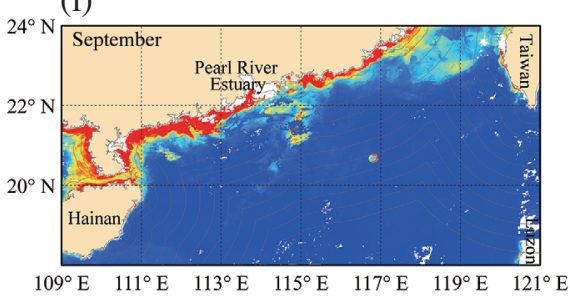

(1)

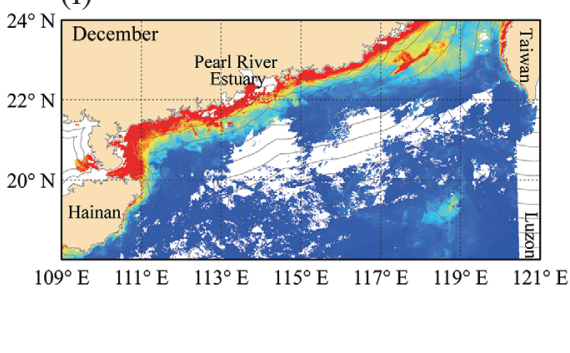

Fig. 4. Spatial distribution of monthly mean Chl-a concentrations $\left(\mathrm{mg} \mathrm{m}^{-3}\right)$ from (a) January to (l) December averaged over the period from 2004 - 2010 in the northern SCS. The beige colored areas represent lands. White color refers to areas without available data. Black lines indicate coastal lines and zonal outlines. The number of data samples used for calculating the averages ranges from one to seven for individual pixels. 
about $1000 \mathrm{~km}$ northeastward from Hainan Island into the Taiwan Strait along the coast of southwestern China.

Figure 5 shows the Chl-a concentration zonal averages in each month from 2004 - 2010. The Chl-a concentration seasonality varied spatially and depended predominantly on the distance from the coastline. In shallow zones the Chl-a concentration showed irregular temporal fluctuations. With the increase in distance from the coastline the fluctuations become small. In contrast, in deep zones the Chl-a concentration exhibited distinguishable seasonal variations, higher in winter and lower in spring. The highest and lowest values occurred in January and May, respectively. In summer the Chl-a concentration increased gradually, followed by a slight decrease prior to a subsequent increase during fall. The seasonal amplitudes in Chl-a concentration were very similar in all deep zones.

The spatial difference in the temporal variations in Chl-a concentration was related to the irregular high nutrient concentration in shallow zones caused by intermittent riverine nutrients from the Pearl River and other tributaries with different drainage basin chemistry, anthropogenic activities and degrees of estuarine recycling (Huang et al. 2003; Cai et al. 2004). The nutrient supplementation in deep zones was derived mainly from subsurface water that regularly and coincidentally fluctuated with the monsoon winds and current (Lee Chen 2005).

\subsection{Inter-Annual Variations of Chl-a Concentration}

Figure 6 presents the inter-annual variability in mean Chl-a concentration in different months, as indicated by the CV for Chl-a concentration for the period from 2004 - 2010. Owing to the lack of good quality Chl-a images, the interannual variations in Chl-a concentration were not discussed for the months of October, November, and December. The inter-annual variations in Chl-a concentration also changed with the season and location. In winter (e.g., February, see Fig. 6b), the low CV values were distributed in the vast areas at the northwest of the Luzon Strait. In summer (e.g., July, see Fig. $6 \mathrm{~g}$ ), the patches of the extremely low CV values occurred in the Taiwan Strait. These low CV values are probably due to the horizontal and vertical current mixing effect. The carrying capacity of the current increased during the winter monsoon periods that induce the nutrient concentration and Chl-a to distribute similarly in winter of all years. Consequently, the inter-annual variability was small. The dissolved inorganic nutrients released from the Luzon arc system were transported mainly by surface currents significantly influenced by the Kuroshio intrusion. Thus, the horizontal mixing was more intense than the vertical mixing. The dissolved inorganic nutrients released from Taiwan were carried mainly by deep water currents (Liu et al. 2010). The vertical mixing was therefore more intense than the horizontal mixing.

Besides the monsoon system, distinct changes occurred in the northern SCS vertical circulation mode during ENSO (Chai et al. 2009; Song 2010). There were one minor (2004) and one prominent (2006) El Niño event, and one prominent (2007 - 2008) La Niña event during the study period from 2004 - 2010 (Sheu et al. 2010). El Niño events mainly strengthened the seasonal mean pattern, strengthened the cyclonic gyre in summer, but weakened the entire cyclonic gyre in winter. In contrast, La Niña events weakened the cyclonic gyre in summer, but strengthened the entire cyclone in winter (Sheu et al. 2010). The vertical mixing between the surface and subsurface water diminished during the weakening winter monsoon in the El Niño years. The diminished vertical mixing also reduced the upward supply of nutrients, leading to a lower Chl-a concentration in the mixed layer,

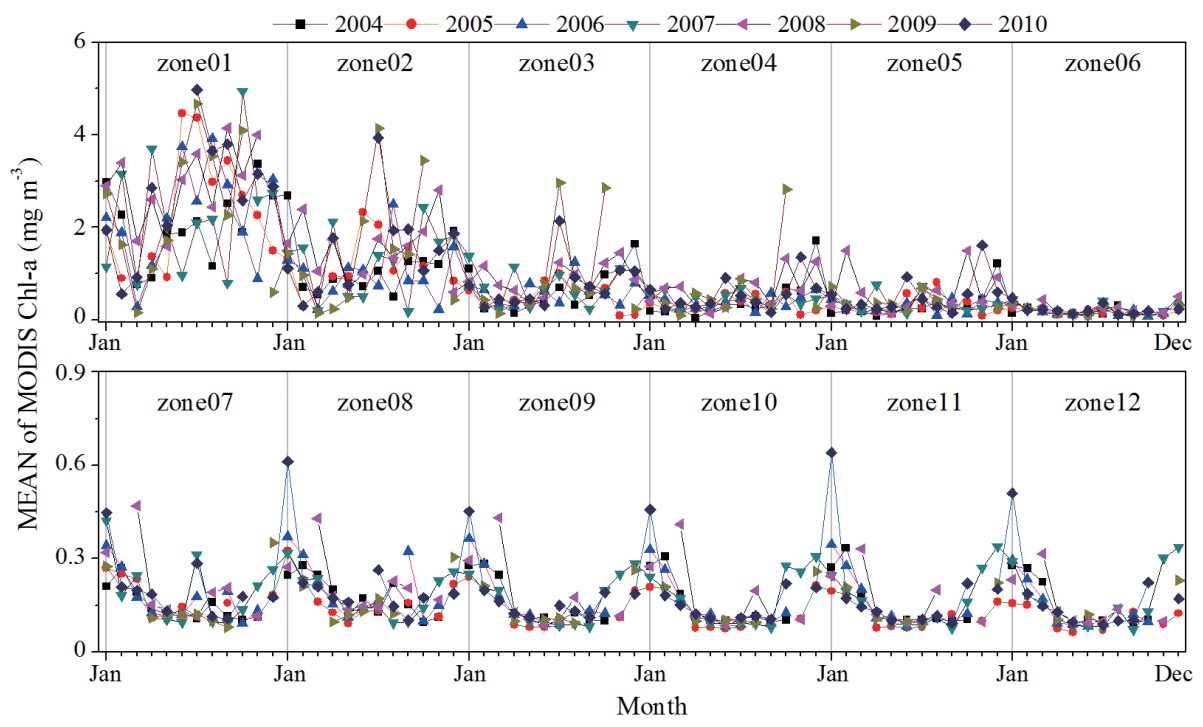

Fig. 5. Monthly Chl-a concentration means in different zones during 2004 - 2010. 
(a)

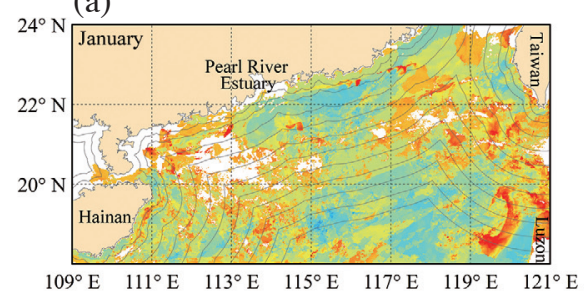

(d)

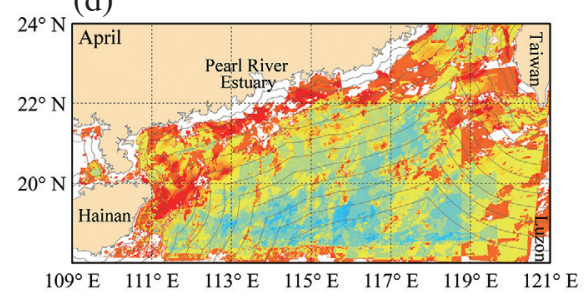

(g)

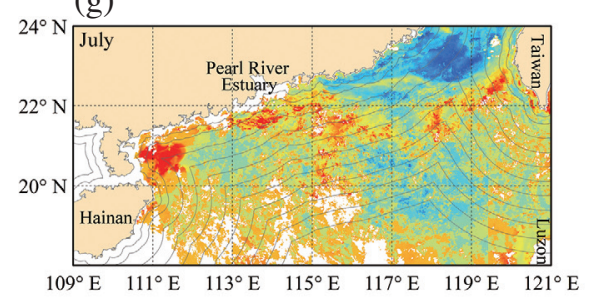

(b)

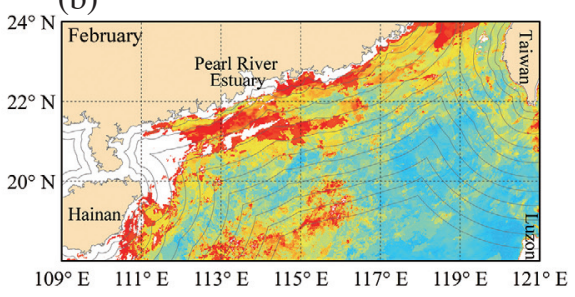

(e)

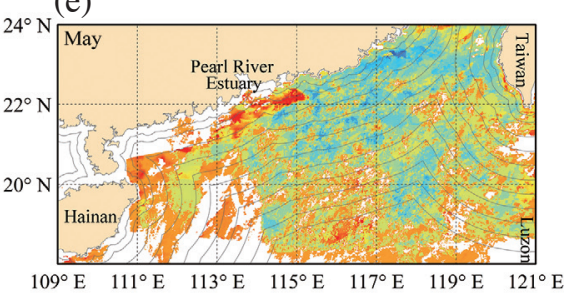

(h)

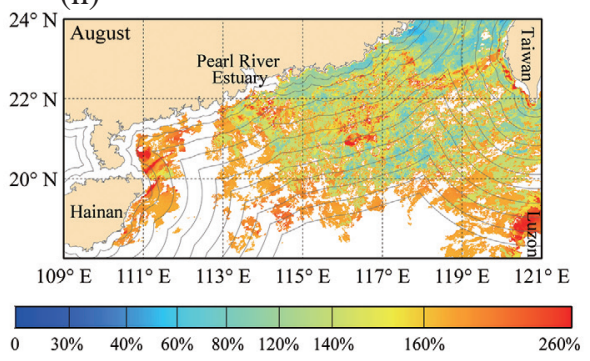

(c)

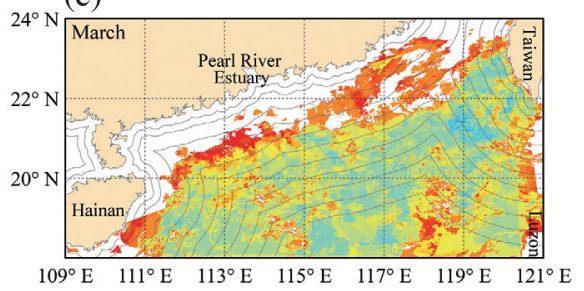

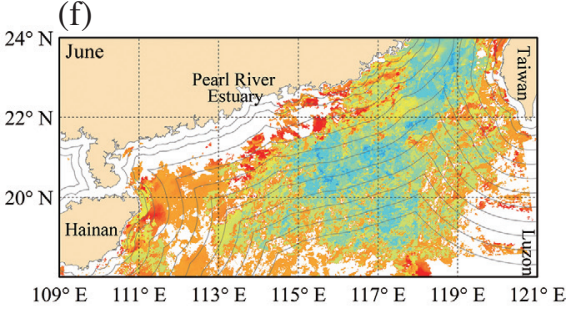

(i)

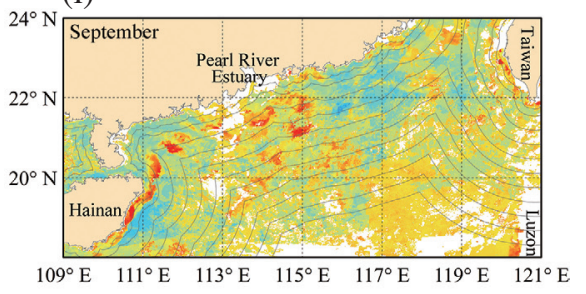

Fig. 6. Spatial distribution of coefficient variance of monthly mean Chl-a from (a) January to (i) September derived from monthly averaged images from 2004 - 2010 in the northern SCS. The beige colored areas represent lands. White color refers to areas without available data. Black lines indicate coastal lines and zonal outlines.

leading further to lower CV values.

\subsection{Zonal Variations of Chl-a Concentration}

The zonal variations in the Chl-a concentration are interpreted in Fig. 7. With the increase in distance from the coastline, the zonal means for the Chl-a concentration generally decreased. The Chl-a concentration decreased quickly from zones $01-03$ and then slowly from zones $04-06$. The Chl-a concentration in far offshore zones $07-12$ was significantly lower than that in the near offshore zones and exhibited barely distinguishable spatial variations. The spatial variations in remotely sensed Chl-a concentration were almost identical to that of the in-situ measurements (Fig. 2). The decreases in Chl-a concentration and its seasonal and inter-annual variations with the distance off the coastline were caused by the coastal environment effect (Huang et al. 2003; Cai et al. 2004; Liu et al. 2012).

\subsection{Linkage of Chl-a Concentration with SST}

The spatial and temporal variations of the sea-surface Chl-a concentration in the northern SCS were affected by nutrient and light availability (Lee Chen 2005). The former played a more prevalent role than the latter in regulating the Chl-a concentration. Nutrient supplementation from the subsurface water was the main source of new nitrogen and fluctuated coincidentally with the monsoon winds, current, and SST (Lee Chen 2005). Besides that, upwelling was the major source of nutrients. The combination of upper ocean circulation and the upwelling contribute to the complicated dynamics of the flow in the northern SCS (Song 2010). A weaker surface flow leads to a strengthened upwelling in the central basin and a weakened down welling in the surrounding area during the El Niño years. This results in a weakened vertical heat advection and a warmer SST (Chao et al. 1996). The effects of above mentioned factors with the spatio-temporal variations in the Chl-a concentration are analyzed further in the following sections.

The SST plays an important role in modulating the Chla concentration spatial variability in the northern SCS. In all months the sea-surface Chl-a concentration correlations with the SST were significantly negative (Fig. 8a). However, the correlations in different zones varied (Fig. 8b). The seasurface Chl-a concentration was negatively and significantly correlated with the SST in the far-offshore zones. The Chl-a and SST were irrelevant in the near-offshore zones (distance off the coastline $<160 \mathrm{~km}$ ), implying that other factors such 
as DIN provided by river runoff and the Longshore current are more important drivers for the temporal variations in Chl-a concentration here.

\subsection{Current Systems Effects on Sea-Surface Chl-a Concentration}

The monsoon system controls the surface circulation in the SCS. The surface current flows southwestward driven by the northeast monsoon in winter whereas it flows in the opposite direction driven by the southwest monsoon in summer (Fang et al. 1998). The upper layer circulation is therefore mostly cyclonic in winter and anti-cyclonic in summer (Hu et al. 2000) (Fig. 9).

In the northern SCS circulation is closely related to inflows and outflows through the Luzon and Taiwan Straits. Data from satellite tracked drifting buoys indicated that the Kuroshio Current could intrude into the SCS in autumn and

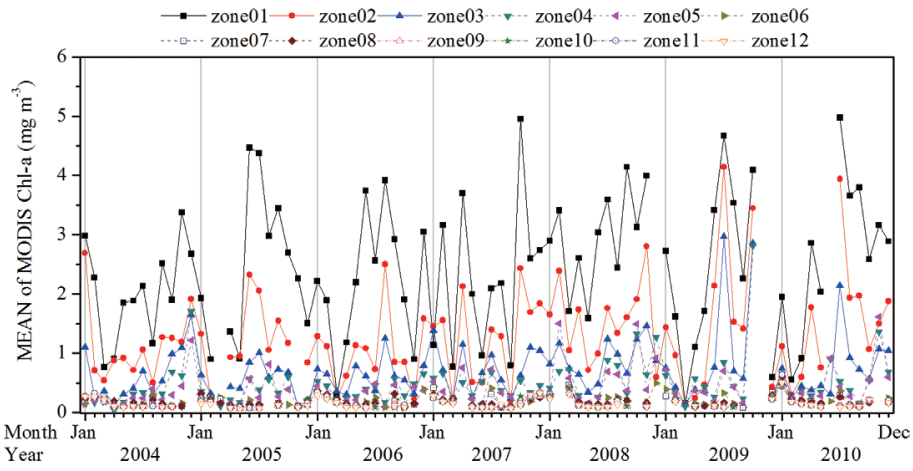

Fig. 7. Zonal means of the Chl-a concentration in different months from 2004 - 2010.

(a)

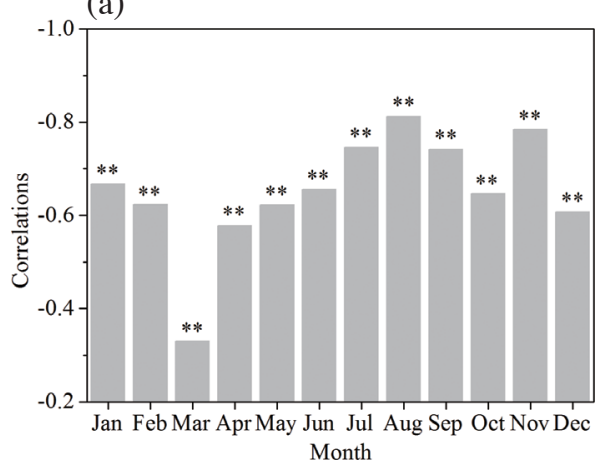

(b)

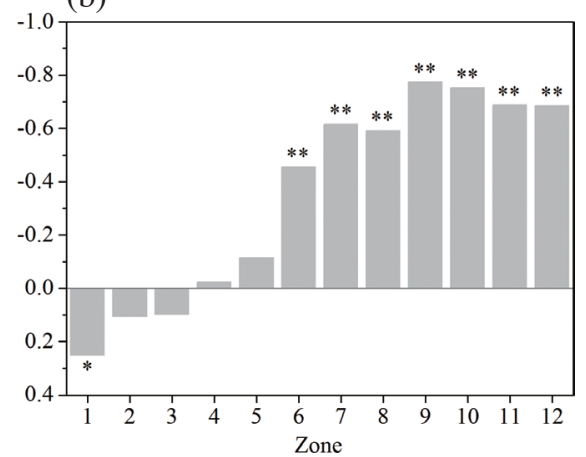

Fig. 8. Correlations between the SST and the Chl-a concentration in (a) different months and (b) different zones. A '*' and '**' indicate significant at the 0.05 level (2-tailed), the 0.01 level (2-tailed), respectively.

(a)

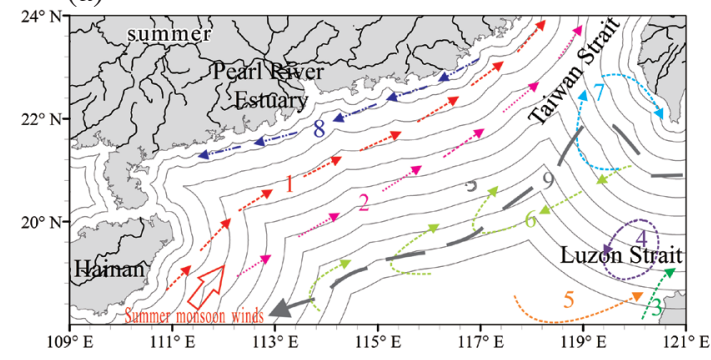

(b)

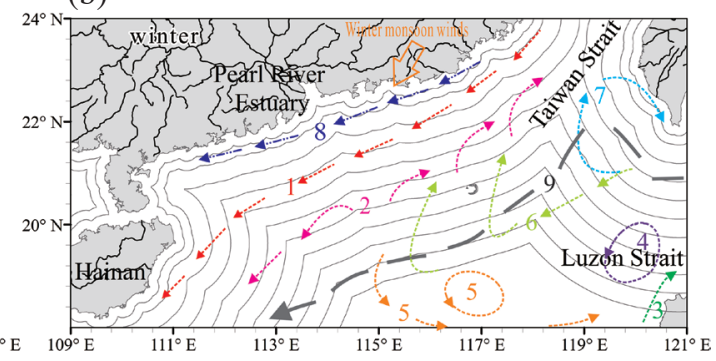

Fig. 9. Monsoon winds and current systems maps for the northern SCS in (a) summer and (b) winter. Monsoon winds after (Webster 1994); surface current after (Shaw and Chao 1994; Fang et al. 1998; Hu et al. 2000); deep current deduced from (Qu et al. 2006); longshore current after (Wang et al. 1986). Numbers for winter and summer currents (Fang et al. 1998; Li et al. 1998; Hu et al. 2000; Caruso et al. 2006; Liu et al. 2010, 2011, 2012): 1, Guangdong Coastal Current; 2, SCS Warm Current (SCSWC); 3, NW Luzon Coastal Current; 4, NW Luzon Cyclonic Eddy; 5, NW Luzon Cyclonic Gyre; 6, SCS Branch of Kuroshio (SCSBK); 7, Loop Current; 8, Longshore Current; 9, Deep water Current. 
winter (Caruso et al. 2006). During autumn the maximum Kuroshio water intrusion reached the western SCS (Xue et al. 2004). After entering the SCS the Kuroshio intrusion splits into three parts: a major part flows out of the SCS through the northern section of the Luzon Strait, the second part, known as the SCS Branch of Kuroshio (SCSBK) that occurs in autumn, flows southwestward along the 1000-m isobaths. The third intrusion feeds the cyclonic eddy west of Luzon Island (Fang et al. 1998; Cai et al. 2002).

The Chl-a concentration was high in areas off northwest Luzon in December (Fig. 4l) and January (Fig. 4a). During this period the study area was affected by the winter monsoon. The Chl-a concentration spatial pattern was related to the sediment transported by the NW Luzon Coastal Current (Fig. 9b) and the regional upwelling off northwest Luzon (Shaw et al. 1996). Upwelled water with high nutrient content spread southwestward as an important nutrient source for the surface water (Shaw et al. 1996). In January the cyclonic eddy of the Chl-a concentration distribution west of the Luzon Strait (Fig. 4a) can be explained by the Loop Current mixing effect (Fig. 9b). From November to February (Figs. 4a, b, k, and l) the Chl-a concentration was high within a band (about $100 \mathrm{~km}$ in width and $1000 \mathrm{~km}$ in length) in the coastal zone. This spatial distribution was driven mainly by the Guangdong Coastal Current and the Longshore Current (Fig. 9b). The Chl-a concentration increased in the direction opposite to the current flow route owing to the decreasing sediment gradient from Taiwan along the current direction.

Compared with large amounts of sediments from the Pearl River and Taiwan Island, sediment discharge from Luzon Island is limited (Liu et al. 2011). Sediments from Luzon Island are confined within the northwest of Luzon Island and hardly transported to the northern shelf of the SCS throughout the SCSBK flow route. This is probably induced by the eddy west of Luzon Island (Fig. 9). Therefore, seasurface $\mathrm{Chl}$-a concentration distribution showed high values in both the coastal zone near the Pearl River estuary and the Taiwan Strait. Additionally, the Chl-a concentration was also high in a small area off northwest Luzon.

In summer the sea-surface Chl-a concentration was relatively low and uniform in the central basin. This phenomenon was probably caused by the dominance of horizontal mixing over vertical mixing. Because of weak winds and large sea surface heating water stratification was well developed in this season. This water stratification limited upwelling of nutrients and phytoplankton growth (Tang et al. 2003). The high Chl-a concentration was only limited to a narrow band along the coast (Figs. 4f, g, and h). The upwelling off the coast was an important player here (Xie et al. 2003). The width of this band was narrower in summer than in winter, which was related to the Guangdong Coastal Current and Longshore Current directions. The flow routes of these two currents are opposite (Fig. 9b), limiting nutrient dispersion.

In summary, several factors in the northern SCS, includ- ing the monsoon winds, current and the upwelling, impact the sea-surface Chl-a concentration distribution by affecting the sediment sources, distribution areas and mixing methods.

\section{CONCLUSIONS}

With the MODIS Chl-a product and other auxiliary data the spatio-temporal variations in the sea-surface Chl-a concentration in the northern SCS were analyzed. The corresponding drivers were explored. From this study the following conclusions can be drawn:

(1) The MODIS Chl-a concentration was significantly consistent with the observations. In general the Chl-a concentration was much higher in the coastal areas than in the open waters. A decreasing gradient was observed from inshore to offshore. The high Chl-a concentration occurred primarily within a belt that is approximately parallel to the sea shoreline of Guangdong province, extending about $1000 \mathrm{~km}$ northeastward from about $110^{\circ} \mathrm{E}$ and $20^{\circ} \mathrm{N}$ to about $118^{\circ} \mathrm{E}$ and $24^{\circ} \mathrm{N}$. The highest Chl-a concentration existed in areas near the Pearl estuary and the Taiwan Strait. The low Chl-a concentration values were found mainly in the vast central area northwest of the Luzon Strait.

(2) The Chl-a concentration exhibited distinct seasonal variations. It was normally higher in winter and peaked in January. The Chl-a concentration was low in spring and approached the lowest value around May. During summer the Chl-a concentration increased gradually and then slightly decreased prior to a second increase in autumn.

(3) The inter-annual variations in Chl-a concentration varied spatially, higher in coastal areas and lower in deep waters. They also changed with the seasons with the lowest values occurring in winter and the highest values in April.

(4) In the northern SCS the complex spatio-temporal variability of the Chl-a concentration was driven by monsoon winds, surface current and SST, owing to their influences on nutrient sources, distribution areas and mixing patterns.

The spatio-temporal variations in the sea-surface Chl-a concentration identified here is valuable for protecting the marine environment and improving the numerical ocean carbon cycle models. However, it should be kept in mind that only MODIS Chl-a data from seven years was used here. The conclusions from this study need further verification using more remote sensing data from different sensors. The forces driving the spatial and temporal variations in Chl-a concentration are complex. Only the influences of monsoon winds, current system, and SST on Chl-a concentration were analyzed here. The integration of remote sensing, pollutant emission and cruiser data with models should be conducted to identify the mechanism and real drivers for the variations in Chl-a concentration.

Acknowledgements We thank the Northern South China 
Sea Opening Research Cruise by R/V Shiyan 3, South China Sea Institute of Oceanology, CAS, and NCEP Reanalysis data provided by the NOAA/OAR/ESRL PSD, Boulder, Colorado, USA, from their Web site at http://www.esrl.noaa.gov/psd/. This study was jointly funded by the National Basic Research Program of China (973 Program) (No. 2010CB950702), the National Nature Science Foundation of China (No. U0933005 and 41206169), and the Hangzhou Normal University scientific research start-up fund (No. 2012QDL047).

\section{REFERENCES}

Blondeau-Patissier, D., G. H. Tilstone, V. Martinez-Vicente, and G. F. Moore, 2004: Comparison of bio-physical marine products from SeaWiFS, MODIS and a bio-optical model with in situ measurements from Northern European waters. J. Opt. A-Pure Appl.Op ., 6, 875-889, doi: 10.1088/1464-4258/6/9/010. [Link]

Boon, A. R. and G. C. A. Duineveld, 1998: Chlorophyll $a$ as a marker for bioturbation and carbon flux in southern and central North Sea sediments. Mar. Ecol. Prog. Ser., 162, 33-43, doi: 10.3354/meps162033. [Link]

Cai, S., J. Su, Z. Gan, and Q. Liu, 2002: The numerical study of the South China Sea upper circulation characteristics and its dynamic mechanism, in winter. Cont. Shelf Res., 22, 2247-2264, doi: 10.1016/S02784343(02)00073-0. [Link]

Cai, W. J., M. Dai, Y. Wang, W. Zhai, T. Huang, S. Chen, F. Zhang, Z. Chen, and Z. Wang, 2004: The biogeochemistry of inorganic carbon and nutrients in the Pearl River estuary and the adjacent Northern South China Sea. Cont. Shelf Res., 24, 1301-1319, doi: 10.1016/j. csr.2004.04.005. [Link]

Carder, K. L., F. R. Chen, J. P. Cannizzaro, J. W. Campbell, and B. G. Mitchell, 2004: Performance of the MODIS semi-analytical ocean color algorithm for chlorophylla. Adv. Space Res., 33, 1152-1159, doi: 10.1016/s02731177(03)00365-x. [Link]

Caruso, M. J., G. G. Gawarkiewicz, and R. C. Beardsley, 2006: Interannual variability of the Kuroshio intrusion in the South China Sea. J. Oceanogr., 62, 559-575, doi: 10.1007/s10872-006-0076-0. [Link]

Chai, F., G. Liu, H. Xue, L. Shi, Y. Chao, C. M. Tseng, W. C. Chou, and K. K. Liu, 2009: Seasonal and interannual variability of carbon cycle in South China Sea: A three-dimensional physical-biogeochemical modeling study. J. Oceanogr., 65, 703-720, doi: 10.1007/ s10872-009-0061-5. [Link]

Chao, S. Y., P. T. Shaw, and S. Y. Wu, 1996: El Niño modulation of the South China Sea circulation. Prog. Oceanogr., 38, 51-93, doi: 10.1016/S0079-6611(96)00010-9. [Link]

Chen, X., Y. S. Li, Z. Liu, K. Yin, Z. Li, O. W. Wai, and B. King, 2004: Integration of multi-source data for water quality classification in the Pearl River estuary and its adjacent coastal waters of Hong Kong. Cont. Shelf Res., 24, 1827-1843, doi: 10.1016/j.csr.2004.06.010. [Link]

Dogliotti, A. I., V. A. Lutz, and V. Segura, 2014: Estimation of primary production in the southern Argentine continental shelf and shelf-break regions using field and remote sensing data. Remote Sens. Environ., 140, 497508, doi: 10.1016/j.rse.2013.09.021. [Link]

Fang, G., W. Fang, Y. Fang, and K. Wang, 1998: A survey of studies on the South China Sea upper ocean circulation. Acta Oceanogr. Taiwan., 37, 1-16.

Hu, J., H. Kawamura, H. Hong, and Y. Qi, 2000: A review on the currents in the South China Sea: Seasonal circulation, South China Sea warm current and Kuroshio intrusion. J. Oceanogr., 56, 607-624, doi: 10.1023/A:1011117531252. [Link]

Huang, X. P., L. M. Huang, and W. Z. Yue, 2003: The characteristics of nutrients and eutrophication in the Pearl River estuary, South China. Mar. Pollut. Bull., 47, 3036, doi: 10.1016/s0025-326x(02)00474-5. [Link]

Kalnay, E., M. Kanamitsu, R. Kistler, W. Collins, D. Deaven, L. Gandin, M. Iredell, S. Saha, G. White, J. Woollen, Y. Zhu, A. Leetmaa, R. Reynolds, M. Chelliah, W. Ebisuzaki, W. Higgins, J. Janowiak, K. C. Mo, C. Ropelewski, J. Wang, R. Jenne, and D. Joseph, 1996: The NCEP/NCAR 40-year reanalysis project. Bull. Amer. Meteorol. Soc., 77, 437-471, doi: 10.1175/15200477(1996)077<0437:TNYRP>2.0.CO;2. [Link]

Lee Chen, Y., 2005: Spatial and seasonal variations of nitrate-based new production and primary production in the South China Sea. Deep-Sea Res. Part I-Oceanogr. Res.Pap., 52,319-340, doi: 10.1016/j.dsr.2004.11.001. [Link]

Li, L., W. D. Nowlin, and J. Su, 1998: Anticyclonic rings from the Kuroshio in the South China Sea. Deep-Sea Res. Part I-Oceanogr. Res. Pap., 45, 1469-1482, doi: 10.1016/S0967-0637(98)00026-0. [Link]

Liu, J., R. Xiang, M. Chen, Z. Chen, W. Yan, and F. Liu, 2011: Influence of the Kuroshio current intrusion on depositional environment in the Northern South China Sea: Evidence from surface sediment records. Mar. Geol., 285, 59-68, doi: 10.1016/j.margeo.2011.05.010. [Link]

Liu, J., W. Yan, Z. Chen, and J. Lu, 2012: Sediment sources and their contribution along northern coast of the South China Sea: Evidence from clay minerals of surface sediments. Cont. Shelf Res., 47, 156-164, doi: 10.1016/j. csr.2012.07.013. [Link]

Liu, K. K., S. Y. Chao, P. T. Shaw, G. C. Gong, C. C. Chen, and T. Y. Tang, 2002: Monsoon-forced chlorophyll distribution and primary production in the South China Sea: observations and a numerical study. Deep-Sea Res. Part I-Oceanogr. Res. Pap., 49, 1387-1412, doi: 10.1016/S0967-0637(02)00035-3. [Link] 
Liu, Z., S. Tuo, C. Colin, J. T. Liu, C. Y. Huang, K. Selvaraj, C. T. A. Chen, Y. Zhao, F. P. Siringan, S. Boulay, and Z. Chen, 2008: Detrital fine-grained sediment contribution from Taiwan to the northern South China Sea and its relation to regional ocean circulation. Mar. Geol., 255, 149-155, doi: 10.1016/j.margeo.2008.08.003. [Link]

Liu, Z., C. Colin, X. Li, Y. Zhao, S. Tuo, Z. Chen, F. P. Siringan, J. T. Liu, C. Y. Huang, C. F. You, and K. F. Huang, 2010: Clay mineral distribution in surface sediments of the northeastern South China Sea and surrounding fluvial drainage basins: Source and transport. Mar. Geol., 277, 48-60, doi: 10.1016/j.margeo.2010.08.010. [Link]

Morton, B. and G. Blackmore, 2001: South China Sea. Mar. Pollut. Bull., 42, 1236-1263, doi: 10.1016/S0025326X(01)00240-5. [Link]

Peñaflor, E. L., C. L. Villanoy, C. T. Liu, and L. T. David, 2007: Detection of monsoonal phytoplankton blooms in Luzon Strait with MODIS data. Remote Sens. Environ., 109, 443-450, doi: 10.1016/j.rse.2007.01.019. [Link]

Prieur, L. and S. Sathyendranath, 1981: An optical classification of coastal and oceanic waters based on the specific spectral absorption curves of phytoplankton pigments, dissolved organic matter, and other particulate materials. Limnol. Oceanogr., 26, 671-689, doi: 10.4319/lo.1981.26.4.0671. [Link]

Qu, T., J. B. Girton, and J. A. Whitehead, 2006: Deepwater overflow through Luzon Strait. J. Geophys. Res., 111, C01002, doi: 10.1029/2005JC003139. [Link]

Sathyendranath, S., G. Cota, V. Stuart, H. Maass, and T. Platt, 2001: Remote sensing of phytoplankton pigments: A comparison of empirical and theoretical approaches. Int. J. Remote Sens., 22, 249-273, doi: 10.1080/014311601449925. [Link]

Shaw, P. T. and S. Y. Chao, 1994: Surface circulation in the South China Sea. Deep-Sea Res. Part I-Oceanogr. Res. Pap., 41, 1663-1683, doi: 10.1016/09670637(94)90067-1. [Link]

Shaw, P. T., S. Y. Chao, K. K. Liu, S. C. Pai, and C. T. Liu, 1996: Winter upwelling off Luzon in the northeastern South China Sea. J. Geophys. Res., 101, 16435-16448, doi: 10.1029/96JC01064. [Link]

Sheu, D. D., W. C. Chou, C. L. Wei, W. P. Hou, G. T. F. Wong, and C. W. Hsu, 2010: Influence of El Niño on the sea-to-air $\mathrm{CO}_{2}$ flux at the SEATS time-series site, northern South China Sea. J. Geophys. Res., 115, C10021, doi: 10.1029/2009JC006013. [Link]

Siegel, D. A., M. J. Behrenfeld, S. Maritorena, C. R. McClain, D. Antoine, S. W. Bailey, P. S. Bontempi, E. S. Boss, H. M. Dierssen, S. C. Doney, R. E. Eplee Jr., R. H. Evans, G. C. Feldman, E. Fields, B. A. Franz, N. A. Kuring, C. Mengelt, N. B. Nelson, F. S. Patt, W. D. Robinson, J. L. Sarmiento, C. M. Swan, P. J. Werdell, T. K. Westberry, J. G. Wilding, and J. A. Yoder, 2013: Regional to global assessments of phytoplankton dynamics from the SeaWiFS mission. Remote Sens. Environ., 135, 77-91, doi: 10.1016/j.rse.2013.03.025. [Link]

Song, J., 2010: Biogeochemical processes of the South China Sea. Biogeochemical Processes of Biogenic Elements in China Marginal Seas, Advanced Topics in Science and Technology in China, Springer-Verlag Berlin Heidelberg, 529-626, doi: 10.1007/978-3-64204060-3_5. [Link]

Tang, D. L., I. H. Ni, F. E. Müller-Karger, and Z. J. Liu, 1998: Analysis of annual and spatial patterns of CZCSderived pigment concentration on the continental shelf of China. Cont. Shelf Res., 18, 1493-1515, doi: 10.1016/S0278-4343(98)00039-9. [Link]

Tang, D. L., I. H. Ni, D. R. Kester, and F. E. Müller-Karger, 1999: Remote sensing observations of winter phytoplankton blooms southwest of the Luzon Strait in the South China Sea. Mar. Ecol. Prog. Ser., 191, 43-51, doi: 10.3354/meps 191043. [Link]

Tang, D. L., H. Kawamura, M. A. Lee, and T. Van Dien, 2003: Seasonal and spatial distribution of chlorophyll$a$ concentrations and water conditions in the Gulf of Tonkin, South China Sea. Remote Sens. Environ., 85, 475-483, doi: 10.1016/s0034-4257(03)00049-x. [Link]

Tilstone, G. H., A. A. Lotliker, P. I. Miller, P. M. Ashraf, T. S. Kumar, T. Suresh, B. R. Ragavan, and H. B. Menon, 2013: Assessment of MODIS-Aqua chlorophyll-a algorithms in coastal and shelf waters of the eastern Arabian Sea. Cont. Shelf Res., 65, 14-26, doi: 10.1016/j. csr.2013.06.003. [Link]

Tseng, C. M., G. T. F. Wong, I. I. Lin, C. R. Wu, and K. K. Liu, 2005: A unique seasonal pattern in phytoplankton biomass in low-latitude waters in the South China Sea. Geophys. Res. Lett., 32, L08608, doi: 10.1029/2004GL022111. [Link]

Venrick, E. L., J. A. McGowan, D. R. Cayan, and T. L. Hayward, 1987: Climate and chlorophyll a: Long-term trends in the central North Pacific Ocean. Science, 238, 70-72, doi: 10.1126/science.238.4823.70. [Link]

Wang, Y., M. E. Ren, and D. Zhu, 1986: Sediment supply to the continental shelf by the major rivers of China. J. Geol. Soc., 143, 935-944, doi: 10.1144/ gsjgs.143.6.0935. [Link]

Webster, P. J., 1994: The role of hydrological processes in ocean-atmosphere interactions. Rev. Geophys., 32, 427-476, doi: 10.1029/94RG01873. [Link]

Xie, S. P., Q. Xie, D. Wang, and W. T. Liu, 2003: Summer upwelling in the South China Sea and its role in regional climate variations. J. Geophys. Res., 108, doi: 10.1029/2003JC001867. [Link]

Xue, H., F. Chai, N. Pettigrew, D. Xu, M. Shi, and J. Xu, 2004: Kuroshio intrusion and the circulation in the South China Sea. J. Geophys. Res., 109, C02017, doi: 10.1029/2002JC001724. [Link] 